\title{
COUNTERING FOREIGN TERRORIST FIGHTERS: WARRANTLESS SURVEILLANCE POWERS OF THE NEW ZEALAND SECURITY INTELLIGENCE SERVICE
}

\author{
Katharine Briar Guilford*
}

\begin{abstract}
On 9 December 2014, the New Zealand Security Intelligence Service Amendment Act 2014 amended the New Zealand Security Intelligence Service Act 1969 by removing the requirement for an intelligence or visual surveillance warrant in some situations of emergency or urgency. The warrant process is the primary mechanism for the purpose of ensuring surveillance powers are not exercised arbitrarily or unreasonably. Any departure from this process must be justified, limited and proportionate. After a brief look at the history of the Bill, this article will then consider the circumstances in which a warrantless authorisation shall be granted and information retained, with reference to the trigger concepts of "terrorist act", "foreign terrorist fighter" and "security". Amendments proposed include limiting the grounds for warrantless surveillance and information retention to countering "foreign terrorist fighters". It will then discuss the consistency of the Bill with the New Zealand Bill of Rights Act 1990, focusing on the authorisation structure and length. It will put forward a proposed amendment that restructures the power such that authorisation for surveillance in urgency will be provided by the Minister and Commissioner within 12 hours.
\end{abstract}

\section{INTRODUCTION}

The traditional divide between domestic and foreign threats has been eroded with global trends in international migration and expanded use of the internet, rapidly pluralising and dispersing the

* Submitted as part of the LLB(Hons) programme at Victoria University of Wellington.. I would like to thank my supervisor Associate Professor Alberto Costi for supporting me throughout the year, asking insightful questions and offering invaluable advice. 
menace posed by foreign terrorist fighters and other violent extremists. ${ }^{1}$ The most recent manifestation of the foreign terrorist threat is the rise of the Islamic State of Iraq and Levant (ISIL), which is responsible for widespread use of indiscriminate and extreme violence primarily in Iraq and Syria. ${ }^{2}$ More than 30,000 foreign terrorist fighters are associated with ISIL, of which an estimated 5,000 hold western passports. ${ }^{3}$ The threat of radicalised foreign fighters causing mass casualties is conducive to anticipatory and preventative counterterrorism measures. An inevitable consequence of this risk dynamic is an intelligence-led approach in which surveillance is conducted on a wide and prescient scale. ${ }^{4}$

New Zealand's Countering Terrorist Fighters Legislation Bill ("the Bill") was introduced to the House of Representatives under urgency on 25 November 2014. It amended three statutes in order to restrict and disrupt travel, monitor and investigate foreign terrorist fighters. ${ }^{5}$ The Committee divided the Bill into the Passports Amendment Bill, Customs and Excise Amendment Bill, and New Zealand Security Intelligence Service Amendment Bill pursuant to Supplementary Order Paper $39 .{ }^{6}$ On 9 December 2014, the amendments became law following a 94-27 party vote in the House. ${ }^{7}$ The New Zealand Security Intelligence Amendment Act 2014 amended the New Zealand Security Intelligence Service Act 1969 by removing the requirement for an intelligence or visual surveillance warrant in some situations of emergency or urgency. ${ }^{8}$

The warrant process is the primary mechanism for the purpose of ensuring surveillance powers are not exercised arbitrarily or unreasonably. Any departure from this process must be justified, limited and proportionate. ${ }^{9}$ This article does not consider whether warrantless surveillance in situations of emergency or urgency is a justifiable extension of powers to the New Zealand Security

1 Office of the Privacy Commissioner of Canada Special Report to Parliament: Checks and Controls: Reinforcing Privacy Protection and Oversight for the Canadian Intelligence Community in an Era of CyberSurveillance (28 January 2014) at 2.

2 Also known as Islamic State (IS), Islamic State in Iraq and Syria or Islamic State in Iraq and al-Sham (ISIS) and Daesh.

3 Soufan Group Foreign Fighters: An Undated Assessment of the Flow of Foreign Fighters into Syria and Iraq (December 2015) at 12.

4 Clive Walker "Keeping Control of Terrorists without Losing Control of Constitutionalism" (2007) 59 Stan L Rev 1395 at 1396.

5 Countering Terrorist Fighters Legislation Bill 2014 (1-2) (select committee report) at 1.

6 Amendments other than ss 4ID and 4IE of the New Zealand Security Intelligence Service Act 1969 lie outside the scope of this article.

7 (9 December 2014) 702 NZPD 1207.

8 New Zealand Security Intelligence Service Act 1969 [NZSIS Act], s 4ID.

9 Privacy Commissioner "Submission to the Foreign Affairs, Defence and Trade Committee on the Countering Terrorist Fighters Legislation Bill" at 3. 
Intelligence Service (NZSIS). Rather, it will discuss the breadth and duration of the power as enacted with a comparative approach and in light of human rights and the principle of legality. In making this analysis, this article seeks to determine whether the scope of the current power is proportionate to the foreign terrorist fighter threat, and put forward possible amendments that will circumscribe the broad enactment.

After a brief look at the history of the Bill, this article will consider the circumstances in which a warrantless authorisation shall be granted and information retained, with reference to the trigger concepts of "terrorist act", "foreign terrorist fighter" and "security". It will then discuss the consistency of the Bill with the New Zealand Bill of Rights Act 1990 (NZBORA), focusing on the authorisation approval structure and period of validity. A few remarks will conclude the article.

\section{IMPETUS FOR THE AMENDMENT}

Spurred by the rise of ISIL, shortly after the 2014 election, Cabinet agreed to a targeted review of capacity, capability and legislation to ensure New Zealand's intelligence and surveillance processes were adequate to respond to the evolving threat of foreign terrorist fighters and violent extremism both locally and internationally. ${ }^{10}$ The focus of the review was interim measures to be taken in advance of the comprehensive review of legislation required to commence before 30 June $2015 .^{11}$ The Bill was the result of the targeted review's recommendations for interim measures. ${ }^{12} \mathrm{~A}$ comprehensive and independent review of legislation was reported to Parliament's Intelligence and Security Committee on 29 February 2016. ${ }^{13}$

The review and provisions are in part a reflection of New Zealand's international obligation to comply with United Nations Security Resolution 2178 as enacted under Chapter VII of the Charter of the United Nations. ${ }^{14}$ This Resolution expressed grave concern over the "acute and growing threat posed by foreign terrorist fighters". ${ }^{15}$ The Resolution reaffirmed that all states shall prevent the movement of terrorists by effective border controls; intensify international information sharing and cooperation; and make efforts to prevent radicalisation, recruitment, financial support and operation

10 John Key, Prime Minister of New Zealand "Speech to New Zealand Institute of International Affairs" (5 November 2014).

11 Department of Prime Minister and Cabinet Regulatory Impact Statement: Foreign Terrorist Fighters Targeted review of relevant legislation (12 November 2014) at 1[2].

12 Countering Terrorist Fighters Legislation Bill 2014 (1-2) (select committee report) at 1.

13 Hon Sir Michael Cullen and Dame Patsy Reddy "Intelligence and Security in a Free Society: Report of the First Independent Review of Intelligence and Security in New Zealand" (February 2016) at [6.92]-[6.105]

14 Department of Prime Minister and Cabinet, above n 11, at 1; and Countering Terrorist Fighters Legislation Bill 2014 (1-2) (select committee report) at 2.

15 SC Res 2178, S/Res/2178 (2014) preamble at 2. 
of foreign fighters. ${ }^{16}$ It leaves to states the responsibility of deciding what legislation is necessary to achieve these goals, consistent with international human rights, humanitarian principles, and refugee law. ${ }^{17}$ Perhaps surveillance is the necessary foundation for practical implementation of these measures, but it is notable that the Resolution does not expressly encourage the expansion of state surveillance powers. Furthermore, it was stated by a member of the Select Committee on the Bill that New Zealand's law before amendment complied with Resolution $2178 .{ }^{18}$ As a result, the Resolution does not provide a solid foundation upon which to enact overbroad legislation. ${ }^{19}$

In October 2014, New Zealand's domestic threat level was raised from very low to low, indicating that a terrorist attack is possible, but not expected. ${ }^{20}$ Government agencies have identified 30 to 40 people of concern, and another 30 to 40 individuals requiring further investigation in a number of centres around New Zealand. ${ }^{21}$ In April 2015, the Director of Security stated that these individuals are involved in a range of activities, including inciting radicalism and funding or facilitating travel for foreign fighters, foreign fighters who have already travelled to the Middle East and people actively planning attacks in New Zealand. ${ }^{22}$ For the year ending 30 June 2014, the NZSIS advised on the cancellation of passports of some monitored individuals intending to travel to Syria, finding that there was a "real likelihood" the lives of those individuals had been saved, and, had those individuals "managed to get to Syria and fight, the NZSIS [had] prevented the risk of battle-hardened individuals returning and compromising New Zealand's security". ${ }^{23}$

Notwithstanding, the targeted review found that urgent situations may arise and, despite processes to expedite warrant application and issuance, the number of hours required for a warrant to be issued may risk the loss of vital intelligence and failure to cancel an individual's passport before they leave New Zealand. ${ }^{24}$ The review, therefore, supported a power of emergency authorisation issued by the

16 At [3]-[4].

17 At [5]; (9 December 2014) 702 NZPD 1207 per Kennedy Graham MP (second reading); and Charter of the United Nations, art 25.

18 (9 December 2014) 702 NZPD 1207 per Fletcher Tabuteau MP (committee of the whole house). .

19 (9 December 2014) 702 NZPD 1207 per Kennedy Graham MP (second reading).

20 John Key "Review of foreign fighters security settings to begin" (press release, 13 October 2014).

21 Countering Terrorist Fighters Legislation Bill 2014 (1-2) (select committee report) at 2.

22 Interview with Rebecca Kitteridge, Director of the New Zealand Security Intelligence Service (Brent Edwards, Insight, Radio New Zealand, 19 April 2015).

23 New Zealand Security Intelligence Service Annual Report: For the year ended 30 June 2014 (G 35, 23 March 2015) at 10.

24 Department of Prime Minister and Cabinet, above n 11, at [18]. 
Director of Security. ${ }^{25}$ It is worthy of note that the review does not refer to an actual situation in which delay inherent in the warrant process has resulted in adverse effects. When introducing the Bill, the Minister for National Security and Intelligence, the Hon Christopher Finlayson spoke to a "hypothetical example" in which the warrantless powers "could" be required. ${ }^{26}$ This suggests that the current warrant system has served the purpose of monitoring and investigating foreign terrorist fighters aptly. Significantly, the authorisation power has not been used since its enactment. ${ }^{27}$

Finally, the review draws parallels with the similar regime for surveillance without a warrant in situations of emergency or urgency in the Search and Surveillance Act 2012 available to law enforcement authorities, ${ }^{28}$ which narrowly became law after passing 61 votes to $57 .^{29}$

The Countering Terrorist Fighters Legislation Bill passed through Parliament under urgency. Two days were allowed for public submission; nearly 600 submissions were received, 23 of which were heard. ${ }^{30}$ The Bill received support at every stage by the National, ACT and United Future parties (62 seats). The Green Party, New Zealand First and the Maori Party opposed it at every stage (27 seats). Labour (32 seats) initially did not support the amendments, but gave an affirmative vote after the Select Committee process. ${ }^{31}$

\section{STATUTORY REOUIREMENTS FOR LEGAL AUTHORITY TO UNDERTAKE SURVEILLANCE}

This part will outline the statutory requirements for the issuance of a warrant, comparing these requirements with those for the issuance of an authorisation by the Director. It will then consider the oversight mechanisms for authorisations, and canvas the emergency warrant procedures of other key Commonwealth jurisdictions.

\section{A Pre-Amendment Powers of the NZSIS}

The NZSIS was established under the New Zealand Security Intelligence Service Act 1969. Its statutory functions are to "obtain, correlate, and evaluate intelligence relevant to security" and

25 At [20]-[21].

26 (25 November 2015) 702 NZPD 781 per Hon Christopher Finlayson (first reading).

27 New Zealand Security Intelligence Service Section 4ID Authorisations Interim Report for the period 1 July 2014 to 31 December 2014 (2 March 2015) at 4; and New Zealand Security Intelligence Service Annual Report: For the year ended 30 June 2015 (G 35, 28 October 2015) at 27.

28 Department of Prime Minister and Cabinet, above n 11, at [19].

29 (22 March 2012) 678 NZPD 1245.

30 (9 December 2014) 702 NZPD 1207 per Kennedy Graham MP (second reading).

31 (9 December 2014) 702 NZPD 1207 per Andrew Little MP (second reading). 
"communicate any such intelligence to such persons, and in such manner, as the Director considers to be in the interests of security". 32

Prior to the Act, there was no avenue through which the NZSIS could legally undertake warrantless surveillance. Interception or seizure of any communication, document or thing not otherwise lawfully obtainable, or the undertaking of electronic tracking, had to be authorised by a warrant jointly issued by the Minister in charge of the NZSIS and the Commissioner of Security Warrants. ${ }^{33}$ The Commissioner of Security Warrants is an individual who has previously held office as a High Court Judge. ${ }^{34} \mathrm{~A}$ domestic intelligence warrant would be issued where the Minister and Commissioner were satisfied that:

(a) the proposed interception, seizure or electronic tracking is "necessary for the detection of activities prejudicial to security"; and

(b) the value of the information sought justified the particular activities; and

(c) the information is not likely to be obtained by any other means; and

(d) any communications sought to be intercepted or seized is not privileged in court proceedings. ${ }^{35}$

The Inspector-General of Intelligence and Security operates the oversight scheme for the warrant process. The Inspector-General's role is to review the effectiveness and appropriateness of procedures adopted by intelligence agencies to ensure compliance with the statutory provisions relating to the issue and execution of warrants. ${ }^{36}$ Reports are published annually canvassing the year ending 30 June. ${ }^{37}$ In 2014, the Inspector-General initiated an own-motion inquiry into actions undertaken by the NZSIS and Department of Prime Minister and Cabinet in 2011. Arising from regular inspection of security warrants, this was the first Inspector-General inquiry into the propriety of particular activities of an intelligence and security agency. ${ }^{38}$

32 NZSIS Act, s 4(1)(a).

33 Section $4 \mathrm{~A}(1)$.

34 Section $5 \mathrm{~A}(3)$.

35 Section $4 \mathrm{~A}(3)$.

36 Inspector-General of Intelligence and Security Act 1996, s 11(d)(i).

37 Section 27(1).

38 Cheryl Gwyn Annual Report for the year ended 30 June 2014 (Office of the Inspector-General of Intelligence and Security, 17 February 2015) at 12. 
On 25 November 2014, the Inspector-General released her report. ${ }^{39}$ The report found that the NZSIS had disclosed incomplete, inaccurate and misleading information; failed to provide clarification once these errors had become apparent and made significant errors in handling media information and OIA. ${ }^{40}$ The report further established that the NZSIS did not have appropriate processes and protocols for the maintenance of political neutrality in its relationship with the Department of Prime Minister and Cabinet; failed to maintain a relationship of trust and confidence with the Leader of the Opposition and undertook an insufficiently rigorous and careful approach to security intelligence. ${ }^{41}$ In what seems to be extremely inopportune timing, the Countering Terrorist Fighters Legislation Bill was introduced to the House the very day this report was released, thereby accompanying proposed extension of intrusive state powers with a weak political foundation and corroded public trust. ${ }^{42}$

\section{B The New Zealand Security Intelligence Service Amendment Act 2014}

On 12 December 2014, the New Zealand Security Intelligence Amendment Act came into force. ${ }^{43}$ It provided two new powers to the NZSIS: warranted visual surveillance powers to detect, investigate or prevent any actual, potential, or suspected terrorist act or facilitation of a terrorist act; and "authorisations" for warrantless surveillance in situations of emergency or urgency. ${ }^{44}$

\section{Section 4ID: warrants need not be obtained in some situations of emergency or urgency}

Under the amended Act, an intelligence warrant or visual surveillance warrant need not be obtained in some situations of emergency or urgency. ${ }^{45}$ The Director of the NZSIS may authorise a person to undertake surveillance without a warrant where the power is necessary "for the detection, investigation, or prevention of any actual, potential, or suspected terrorist act; or facilitation of a terrorist act", the Director is satisfied that the threshold for issuing a warrant is met, obtaining a warrant is impracticable in the circumstances and a delay is likely to result in a loss of intelligence. ${ }^{46}$ An authorisation allows the interception or seizure of any communication, document or thing,

39 Cheryl Gwyn Report into the release of information by the New Zealand Security Intelligence Service in July and August 2011 (Office of the Inspector-General of Intelligence and Security, 25 November 2014).

40 At [9]-[12].

41 At [14]-[21].

42 (9 December 2014) 702 NZPD 1207 per Kennedy Graham MP (second reading).

43 New Zealand Security Intelligence Service Amendment Act 2014.

44 Section 4.

45 NZSIS Act, s 4ID.

46 Section 4ID(1). 
electronic tracking, or visual surveillance. ${ }^{47}$ The authorisation is valid for a period of 24 hours. ${ }^{48}$ Upon expiry, no further application may be made for an authorisation in respect of the same subject matter. $^{49}$

There are a number of differences between the statutory requirements for issue of a warrant as compared with issue of an authorisation granted in situations of urgency or emergency. First, a warrant and an authorisation will enable the exercise of the same surveillance practices at the same level of intrusiveness, namely the interception or seizure of any communication, document, electronic tracking, or visual surveillance. ${ }^{50}$ Secondly, the approval process for the issuance of a warrant differs from that of an authorisation. Warrants are approved jointly by the Minister in charge of the NZSIS and the Commissioner of Security Warrants upon application by the Director of the NZSIS. ${ }^{51}$ The Director of the NZSIS issues authorisations. ${ }^{52}$ The result is that where surveillance under a warrant is authorised by an independent and impartial authority, an authorisation is self-authorised by the organisation that is to exercise the intrusive powers the authorisation enables. ${ }^{53}$ Thirdly, intelligence warrants may be issued where they are necessary for detection of "activities prejudicial to security", whereas authorisations may only be issued on the more limited ground of necessity for detection of a terrorist act or facilitation of a terrorist act. ${ }^{54}$ Fourthly, in addition to satisfaction that grounds for a warrant are fulfilled, authorisations additionally require that obtaining a warrant is impracticable and is likely to result in loss of intelligence. ${ }^{55}$ Finally, warrants may be valid for a period up to 12 months and may be renewed in respect of the same subject matter. ${ }^{56}$ Authorisations are valid for a period of 24 hours, and may not be renewed unless a warrant is granted in respect of that subject matter. ${ }^{57}$

\footnotetext{
47 Section 4ID(2).

48 Section $4 \operatorname{ID}(3)$.

49 Section 4ID(4).

50 Sections $4 \mathrm{~A}(1), 4 \mathrm{IB}(1)$ and $4 \operatorname{ID}(2)$.

51 Section $4 \mathrm{~A}(1)$

52 Sections $4 \mathrm{~A}(1)$ and $4 \mathrm{~A}(4), 4 \mathrm{IB}(1)$ and $4 \mathrm{IB}(5)$ and $\mathrm{s} 4 \mathrm{ID}(1)$.

53 Amnesty International and Human Rights Foundation of Aotearoa New Zealand "Submission to the Independent Panel Reviewing New Zealand's Intelligence and Security Agencies" (17 August 2015) at 4.

54 NZSIS Act, ss 4A(3)(a), 4IB(3)(a) and 4ID(1)(a).

55 Section $4 \operatorname{ID}(1)(\mathrm{c})$.

56 Sections $4 \mathrm{C}$ and $4 \mathrm{IC}(1)(\mathrm{c})$.

57 Sections 4ID(3) and 4ID(4)
} 


\section{Section 4IE: oversight after an authorisation has been issued}

Section 4IE contains an oversight scheme operating after an authorisation has been issued. Immediately after an authorisation is given, the Director must advise the Minister, the InspectorGeneral and, where appropriate, the Commissioner. ${ }^{58}$ The Minister or the Commissioner may direct the NZSIS to discontinue activity under the authorisation and destroy any information collected without delay. ${ }^{59}$ If the Minister or Commissioner makes such a direction, the Director must refer the matter to the Inspector-General for investigation. ${ }^{60}$ It is the responsibility of the Director to ensure that any directions are carried out without delay. ${ }^{61}$

After expiry of an authorisation, if no application has been made for a warrant, the Director must provide a report to the Minister or, where appropriate, the Commissioner. ${ }^{62}$ This report must include the reasons for which the authorisation was given, the reasons for which there was no warrant subsequently applied for, and details as to the nature of the information collected under the authorisation. ${ }^{63}$ The Minister or Commissioner must determine whether it was appropriate for that authorisation to have been given, and refer the matter to the Inspector-General for investigation. ${ }^{64}$ If an authorisation is followed by a warrant application that is refused, the Director must refer the matter to the Inspector-General for investigation. ${ }^{65}$

If no warrant is issued in relation to the authorisation, the Minister must ensure that any records are destroyed except information that may be prejudicial to security. ${ }^{66}$ The decision to retain records must be referred to the Inspector-General for investigation. ${ }^{67}$ The breadth of this retention clause raises questions because it allows information to be retained on grounds wider than that for which it was authorised to be collected. In other words, authorisations are issued in circumstances necessary to detect a terrorist act or the facilitation of a terrorist act, whereas information may be retained on grounds relating to the prejudice of security, which is a wider concept. Thus, information may be
58 Section 41E(1).
59 Section $41 \mathrm{E}(2)$.
60 Section 41E(4).
61 Section $4 \operatorname{IE}(3)$.
62 Section 41E(5).
63 Sections $41 \mathrm{E}(5)-(6)$.
64 Section 4IE(7).
65 Section 41E(8).
66 Section 4IE(9).
67 Section $41 \mathrm{E}(10)$. 
retained even where its collection was not initially authorised. This issue will be considered in more depth in Part III.

Evidently, the Inspector-General operates the integral oversight mechanism for the exercise of authorisation powers. However, debate in the House raised concerns regarding the statutory political neutrality, independence and powers of the Inspector-General to ensure intelligence and security agencies comply with the law, given the advisory role of the office. ${ }^{68}$ The powers and role of the Inspector-General were reviewed in the wider intelligence and security community review, completed on 29 February $2016 .{ }^{69}$

Sections 4IE(12), 4IE(13) and 4IE(14) impose interim six-monthly and annual reporting requirements to be prepared by the Director to be delivered to the Minister. ${ }^{70}$ The Act contains a sunset clause set to expire on 1 April 2017. ${ }^{71}$

\section{Use of information and possible redress for individuals subject to improper surveillance}

Information gained or the existence of a warrant may not be disclosed otherwise than in the strict course of official duties or as authorised by the Minister. ${ }^{72}$ While the Act does not expressly provide that intelligence may be used as evidence, it is difficult to conceive of any other purpose for the collection of intelligence and there are Canadian and Australian precedents that assume this is the case. ${ }^{73}$ Moreover, the Act does not address the admissibility of evidence collected through warrantless surveillance, or the admissibility of evidence where a warrant subsequent to an authorisation was denied or not sought. ${ }^{74}$ While courts are able to exclude evidence that results from an improper search, it is improper to enact legislation with clear loopholes and expect the courts to provide remedial cover. $^{75}$

68 (9 December 2014) 702 NZPD 1207 per Hon Phil Goff MP and David Shearer MP (committee of the whole house).

69 Cullen and Reddy, above n 13.

70 NZSIS Act, s 41E(12)-(14).

71 Section $41 \mathrm{G}$.

72 Section $12 \mathrm{~A}$.

73 Parkin v O'Sullivan [2006] FCA 1413; (2006) 162 FCR 444; and Charkaoui v Canada (Citizenship and Immigration) 2008 SCC 38; [2008] 2 SCR 326 as cited in Roger Douglas Law, Liberty, and the Pursuit of Terrorism (University of Michigan Press, Ann Arbor, 2014) at 71.

74 Human Rights Lawyers Association Aotearoa "Submission to the Foreign Affairs, Defence and Trade Select Committee on the Countering Terrorist Fighters Bill 2014" at 2.4.5.

75 At 2.4.6 
The rights of an individual subjected to improper surveillance are not set out in the enactment. In the security intelligence context, the challenge in gaining access to judicial review or successfully filing a complaint with the Inspector-General, Ombudsman or Privacy Commissioner is that individuals are required to be aware of the surveillance. Comments about security organisations generally note that such awareness is precluded by the clandestine nature of the surveillance programmes and, as a result, individuals may not have a legal avenue for redress. ${ }^{76}$ Where police overstep their powers in the course of criminal investigation, that activity will be tested in court. By contrast, security organisations face the prospect of accountability only where oversight mechanisms raise an issue or information morphs into criminal proceedings. ${ }^{77}$

As an illustration of the situation in New Zealand, in the past five years the Inspector-General has recorded only a handful of errors and complaints, none of which resulted in compensation. Three complaints relating to harassment and surveillance have been made, none of which were upheld. ${ }^{78}$ Corrective action following two errors in 2010 meant that "[n]o apparent harm to anyone had followed". ${ }^{79}$ Similarly in 2014, information collected from inadvertent surveillance of a third party was deleted and no further action was determined as necessary. ${ }^{80}$ In 2015 , an issue was raised in which the NZSIS's first two visual surveillance warrants were not reported to the Inspector-General and appropriate arrangements to remedy this defect were subsequently made. ${ }^{81}$ Importantly, this report also found that the NZSIS lacked a compliance framework and policy, audit framework and dedicated staffing such that there was "no general, objective safeguard against breaches of legislation or policy and no general assurance that breaches would be identified and addressed". 82

\section{Other Commonwealth jurisdictions}

This part will place New Zealand's counterterrorism surveillance legislation within the counterterrorism surveillance policies of New Zealand's Five Eyes counterparts. It is important firstly

76 Martin Scheinin Report of the Special Rapporteur on the promotion and protection of human rights and fundamental freedoms while countering terrorism A/HRC/13/37 (2009) at [38].

77 Craig Forcese and Kent Roach "Bill c51: the Good, the Bad ... and the Truly Ugly" (13 February 2015) $<$ thewalrus.ca>.

78 DP Neazor Inspector-General of Intelligence and Security Annual Report 2011 (Office of the InspectorGeneral of Intelligence and Security, 11 October 2011) at [8]; DP Neazor Inspector-General of Intelligence and Security Annual Report 2012 (Office of the Inspector-General of Intelligence and Security, November 2012) at [10.d].

79 DP Neazor, Inspector-General of Intelligence and Security Annual Report 2010 (Office of the InspectorGeneral of Intelligence and Security, 16 November 2010) at [31].

80 Cheryl Gwyn, above n 39, at 21.

81 Cheryl Gwyn Annual Report for the year ended 30 June 2015 (Office of the Inspector-General of Intelligence and Security, 21 October 2015) at 33.

82 At 41. 
to understand the different terrorist threat levels that each of these states face so as to consider the necessity for invasive surveillance measures. As a reminder, New Zealand's threat level has recently been raised from very low to low, indicating that a terrorist attack is possible, but not expected. ${ }^{83}$ Canada assesses its threat level at medium. ${ }^{84}$ Australia currently has a threat level of "probable" (individuals or groups have developed both an intent and capability to conduct a terrorist attack in Australia) and the UK "severe" (a terrorist attack is highly likely). ${ }^{85}$ As a consequence of a higher terrorist threat assessment, these states have greater capacity and capability coupled with extensive anti-terrorism laws. Moreover, all have also recently accounted further strengthening of their legislative frameworks. ${ }^{86}$

At the request of the Select Committee, the Department of the Prime Minister and Cabinet released a statement comparing provisions of the Bill with the legal standards in Australia and the United Kingdom. $^{87}$

The legislative foundation in Australia for urgent surveillance is the Australian Security Intelligence Organisation Act 1979 (ASIO Act), s 29. The statement represented that the DirectorGeneral of the Australian Security Intelligence Organisation (ASIO) may issue emergency warrants where the Director is satisfied of "reasonable grounds for believing" that the surveillance will substantially assist the collection of intelligence relating to security. ${ }^{88}$ On its face, this is correct, but the statement did not mention the integral s 29(1)(a). This provision requires that the Director-General may issue a warrant where "the Director-General has forwarded or made a request to the Minister for the issue of a warrant". ${ }^{89}$ The operation of this paragraph is to dictate that surveillance may only be authorised by the Director-General after a warrant has been applied for. Emergency warrants are valid for a period not exceeding 48 hours. ${ }^{90}$

83 Key, above n 20.

84 Office of the Minister of Public Safety and Emergency Preparedness (Canada) "Statement from Canada's Minister of Public Safety and Emergency Preparedness on the terrorist attack in Paris" (Ottawa, 24 November 2015).

85 Michael Keenan and George Brandis "New National Terrorism Thread Advisory System" (press release, 26 November 2015); and MI5 "Threat Levels" (11 May 2016) <www.mi5.gov.uk>.

86 Office of the Minister for National Security and Intelligence Foreign Terrorist Fighters - Targeted Review of Capability, Capacity and Legislation (October 2014) at [31].

87 Department of the Prime Minister and Cabinet Countering Terrorist Fighters Legislation Bill - Comparison with other jurisdictions (28 November 2014).

88 At [5].

89 Australian Security Intelligence Organisation Act 1979 (Aus), s 29(1)(a).

90 Section 29(2). 
New Zealand's emergency authorisations are granted in more limited counterterrorism circumstances than Australian emergency warrants. New Zealand's authorisations also extend for half the period of Australia's emergency warrants. However, Australian emergency warrants may only be issued where a warrant application has already been made to the Minister. This suggests that the Australian security services do not consider the time to collate evidence for a warrant a disproportionate threat to their ability to collect vital information.

The statement then references the Security Service Act 1989 s 3(b) as the legislative foundation for the United Kingdom MI5's power to undertake urgent surveillance. ${ }^{91}$ However, this section of the Act was repealed and superseded in 1994. ${ }^{92}$ The current legislative provisions for urgent surveillance conducted by MI5 are found in the Regulation of Investigatory Powers Act 2000. A warrant will be granted in circumstances of national security, for the detection or prevention of serious crime, and for safeguarding the economic well-being of the United Kingdom. ${ }^{93}$ Warrants for interception of communication and intrusive surveillance in an urgent case will only be issued where the Secretary of State has expressly authorised their issue. ${ }^{94}$ An urgent interception warrant will last for a period of five working days. ${ }^{95}$

The United Kingdom's emergency powers are granted in considerably wider circumstances and are valid for a significantly longer period than New Zealand's emergency authorisations. However, the United Kingdom's urgency provision requires the Secretary of State (for these purposes, the actor equivalent to New Zealand's Minister in charge of the New Zealand Security Intelligence Service and Commissioner of Security Warrants) to personally authorise the warrant. This is strictly contrasted with New Zealand's legislation that requires notification of the Minister and Commissioner who have a power to discontinue the surveillance, but do not positively authorise it until a warrant has been issued. ${ }^{96}$

Though not referred to in the departmental report, the Canadian Security Intelligence Service has no statutory authority to undertake warrantless surveillance. Under s 21(1) of the Canadian Security Intelligence Service Act 1984, if a warrant is required for investigation of a threat to security, applications are made to a Federal Court judge after having obtained the Minister's approval. ${ }^{97}$ The Canadian Security Intelligence Service does not have a warrantless domestic surveillance power, as

91 Department of Prime Minister and Cabinet, above n 87, at [10].

92 Security Service Act 1989 (UK), s 3(b).

93 Regulation of Investigatory Powers Act 2000 (UK), s 5(3).

94 Sections 7(2)(a) (interception of communications), 42(1) and 44(2) (intrusive surveillance).

95 Section 9(6)(a).

96 NZSIS Act, s 4IE(2).

97 Canadian Security Intelligence Service Act 1985 (Can), s 21(1). 
contrasted with the recent introduction of this power to be utilised by the New Zealand Security Intelligence Service. Moreover, Canada's legislation requires warrants for conducting surveillance to be made by a separate and independent authority with adequate resources and competency to make judicial assessments of the legality of the surveillance, the technology used and human rights. ${ }^{98}$

\section{WARRANTLESS SURVEILLANCE: NECESSARY, JUSTIFIED AND PROPORTIONATE?}

The Office of the United Nations High Commissioner for Human Rights has stated that: "[t]errorism aims at the very destruction of human rights ... and the rule of law" ${ }^{99}$ However, the flip side is that "[m]easures to combat terrorism may also prejudice the enjoyment of - or may violate human rights and the rule of law". ${ }^{100}$ As a result, counterterrorism best practice requires that the exercise of functions and powers be based on the principle of legality and that restrictions on rights shall be proportionate to the benefit obtained. ${ }^{101}$ For example, a recommendation to New Zealand following its second Universal Periodic Review by the United Nations Human Rights Council was to ensure that legislation on surveillance complies with the principle of proportionality, and that its counterterrorism legislation is in full compliance with the International Covenant on Civil and Political Rights (ICCPR). ${ }^{102}$

\section{A Principle of Legality}

Respect for the rule of law means that the principle of legality cannot be compromised. ${ }^{103}$ This principle is enshrined in art 15 of the ICCPR and is non-derogable, even in times of public emergency. ${ }^{104}$ It is implicit in this principle that laws contain clear and precise provisions, so as to ensure that the law is not subject to interpretation that would unduly broaden the scope of the proscribed conduct. ${ }^{105}$ Following investigation in Chile, the Special Rapporteur on the promotion and

98 Amnesty International and Human Rights Foundation of Aotearoa New Zealand, above n 53, at 4.

99 Office of the United Nations High Commissioner for Human Rights Fact Sheet No 32: Human Rights, Terrorism and Counter-terrorism (July 2008) at 7.

100 Martin Scheinin Report of the Special Rapporteur on the promotion and protection of human rights and fundamental freedoms while countering terrorism A/HRC/16/51 (2010) at [8].

101 At [15]-[16].

102 United Nations Human Rights Council Report of the Working Group on the Universal Periodic Review: New Zealand A/HRC/26/3 (2014) at [218.154]-[218.155].

103 Kim Lane Scheppele "Global Security law and the Challenge to Constitutionalism after 9/11" (2011) 2 PL 354 at 365 .

104 International Covenant on Civil and Political Rights 999 UNTS 171 (opened for signature 16 December 1966, entered into force 23 March 1976) [ICCPR], art 15.

105 Office of the United Nations High Commissioner for Human Rights, above n 99, at 40. 
protection of human rights and fundamental freedoms while countering terrorism has recently recommended that "[i]n particular, the definitions of terrorist crimes should be confined exclusively to activities that entail or are directly related to the use of deadly or serious violence against civilians". 106

Applied to the New Zealand Security Intelligence Service Act 1969, the principle of legality requires that the Act's provisions are formulated in explicit, precise and confined terms such that an individual may be reasonably aware of the conditions and circumstances under which the authorities are empowered to conduct warrantless surveillance measures. ${ }^{107}$ The principle of legality is implicated in two principal ways in s 4ID. The first is the trigger concept of the discretion to authorise warrantless surveillance as necessity to detect a "terrorist act". ${ }^{108}$ This concept is ambiguous and therefore undermines the clarity and certainty that the principle of legality seeks to uphold. The United Nations Human Rights Council has emphasised the undesirability of such legislation, stating that "[an] imprecise definition of a crime can lead to the criminalization of innocent conduct and to the broadening of proscribed conduct in judicial interpretation". ${ }^{109}$ As a result, individuals may be subject to the special powers the state has reserved for counterterrorism. ${ }^{110}$ The second is a failure of the legislation to circumscribe the application of the warrantless surveillance power to foreign fighters. In other words, despite grey areas at the fringe of definition, the term "terrorist act" is considerably wider than the concept of "foreign fighter". This dynamic implicates the principle of legality because the discretion to conduct warrantless surveillance in the context of the threat of terrorism could be applied to conduct that is not directly related to the concept of foreign fighters.

\section{Definition of "terrorist act"}

The definition of "terrorist act" is contained in s 5 of the Terrorism Suppression Act 2002. The term encompasses acts that constitute an offence as defined in a specified terrorism convention, ${ }^{111}$ or acts that are carried out "for the purpose of advancing an ideological, political, or religious cause" that

106 Ben Emmerson Report of the Special Rapporteur on the promotion and protection of human rights and fundamental freedoms while countering terrorism addendum: Mission to Chile A/HRC/25/59/Add.2 (2014) at [93].

107 Amnesty International and Human Rights Foundation of Aotearoa New Zealand, above n55, at 4.

108 NZSIS Act, s 4ID(1)(a).

109 United Nations Human Rights Council Report of the United Nations High Commissioner for Human Rights on the protection of human rights and fundamental freedoms while countering terrorism A/HRC/28/28 (2014) at [21].

110 Kent Roach "Defining Terrorism: The Need for a Restrained Definition" in Craig Forcese and Nicole LaViolette (eds) The Ottawa Principles of Human Rights and Counter-Terrorism (Irwin Law, Toronto, 2008) 97 at 98; and Office of the United Nations High Commissioner for Human Rights, above n 99, at 40.

111 Terrorism Suppression Act 2002, sch 3: unlawful seizure of aircraft, civil aviation, international crimes, taking of hostages, maritime navigation, fixed platforms, bombings, nuclear material and nuclear terrorism. 
intend to induce terror in a civilian population or unduly compel a government or international organisation to do or abstain from doing any act. ${ }^{112}$ Acts of the latter type also require a harm element, such that the act must be intended to cause:

- death or serious bodily injury; or

- $\quad$ "serious risk to the health or safety of a population"; or

- $\quad$ serious interference or disruption to an infrastructure facility, "if likely to endanger human life"; or

- "destruction of, or serious damage to, property of great value or importance, or major economic loss, or major environmental damage" if likely to result in the aforementioned outcomes; or

- $\quad$ "introduction or release of a disease-bearing organism, if likely to devastate the national economy of a country". 113

Section 25(1) of the Act extends at length the definition into the inchoate period by legislating that a terrorist act is carried out where planning or preparations to carry out the act, whether it is carried out or not, a credible threat to carry out the act, an attempt to carry out the act or the actual carrying out of the act. ${ }^{114}$ A terrorist act is facilitated if there is knowledge that a terrorist act is being facilitated, but this does not require that the facilitator knows specifically that any act is foreseen or planned, or that the act is ultimately carried out. ${ }^{115}$ The definition contains an avoidance of doubt safeguard stating that "the fact that a person engaged in any protest, advocacy, or dissent, or engages in any strike, lockout, or other industrial action" alone is not sufficient basis for inferring the requisite purpose or intention. ${ }^{116}$

The definition has been criticised by the New Zealand Human Rights Commission as "open to interpretation" with the potential to be "applied very broadly by law enforcement and intelligence officials". ${ }^{117}$ For example, New Zealand's only charges under the Terrorism Suppression Act were dropped after the Solicitor-General concluded that "the legislation is unnecessarily complex,

112 Section 5(2).

113 Section 5(3).

114 Section 25(1).

115 Section 25(2).

116 Section 5(5).

117 Human Rights Commission Operation Eight: a human rights analysis (December 2013) at [79]. 
incoherent and as a result almost impossible to apply" to the circumstances of the case. ${ }^{118}$ This ambiguity as to the precise definition of "terrorism" is found in other jurisdictions: the Canadian, New Zealand and Australian definitions of terrorism are based to a considerable extent on the United Kingdom's definition. ${ }^{119}$ The implication of widespread ambiguity is perhaps that it would be more desirable to limit invasive surveillance powers to a more clearly demarcated concept of terrorist, such as the definition of foreign fighter. While not a perfect definition, to circumscribe discretion to a narrower set of circumstances would reduce the risk of inappropriately invoked powers of warrantless surveillance.

\section{2 "Terrorist" versus "foreign fighter"}

The breadth of the definition poses particular problems in the context of warrantless surveillance. The originating sources of the threat for which the legislation was enacted are the foreign terrorist fighter, violent extremism and radicalisation. ${ }^{120}$ However, the Bill did not define these terms, or use them in the substantive enactments. The Hon Christopher Finlayson, Minister in Charge of the New Zealand Security Intelligence Service, stated that the Government considered the terms did not need a specific definition because the definition of "terrorist act" in $\mathrm{s} 5$ of the Terrorism Suppression Act is adequate: $:^{121}$

We are targeting people by behaviour or intended behaviour, not by a label. The bill targets people who want to carry out a terrorist act ... people who want to go and fight for the Islamic State of Iraq and the Levant ... are just the latest manifestations of the terrorist acts already envisaged by, and defined in, the Terrorism Suppression Act.

However, the definition of a terrorist act is overly broad for the purpose of countering foreign terrorist fighters. To understand this mismatch, we must first understand what a foreign terrorist fighter is. Resolution 2178 provides the definition as: ${ }^{122}$

... individuals who travel to a State other than their States of residence or nationality for the purpose of the perpetration, planning, or preparation of, or participation in, terrorist acts or the providing or receiving of terrorist training, including in connection with armed conflict ... .

118 David Collins QC Decision of the Solicitor-General in Relation to the Prosecution of People under the Terrorism Suppression Act 2002 ("Operation 8") (Crown Law, 8 November 2007) at [8].

119 Douglas, above n 73, at 51-53

120 Countering Terrorist Fighters Legislation Bill 2014 (1-2) (select committee report) at 1.

121 (9 December 2014) 702 NZPD 1207 per Hon Chris Finlayson (second reading).

122 SC Res 2178, above n 15, preamble at 2 (emphasis added). 
One of the defining elements of a foreign terrorist fighter is that an individual leaves his or her country of origin. ${ }^{123}$ The current definition of "terrorist act" and trigger concept for warrantless surveillance, however, does not distinguish between suspected acts committed by the foreign terrorist fighter, and domestic threats. Domestic actors, while undeniably a threat to national security, are thereby implicated under legislation that is enacted to address a distinguishable threat.

The domestic threat of terrorism does not provide justification for warrantless surveillance powers for any form of terrorism, as distinct from the risk of foreign fighters leaving New Zealand. New Zealand's threat level remains at low: the threat of a terrorist attack is assessed as possible, but not expected. An unexpected threat does not justify unprecedented expansion of an intrusive state power that has the potential to apply very broadly. ${ }^{124}$ The Law Society stated in reference to the Bill that where legislation "which has such a potential to profoundly impact on human rights" is being considered, "[p]ublic input and debate is essential". ${ }^{125}$ Therefore, if warrantless surveillance is to justifiably extend to the domestic sphere, it is imperative that debate and public consultation consider the full breadth of its implications.

For now, introduction of a definition of a foreign fighter and subsequent limitation of the power to these terms are imperative. For instance, legislators should return to Supplementary Order Paper (SOP) Number 42 introduced by Kennedy Graham of the Green Party that failed to pass in the House following a 48-73 vote. ${ }^{126}$ This SOP proposed the insertion of a threefold purpose statement into each of the amending bills to provide clarity and interpretive instruction for the extent to which the new powers can be exercised. ${ }^{127}$ In respect of the NZSIS, the SOP sought to introduce a section 41AA: ${ }^{128}$

\section{IAA Purpose}

(1) The purpose of sections 4IA to 4IG is to ensure that New Zealand-

123 See Geneva Academy of International Humanitarian Law and Human Rights Academy Briefing No 7: Foreign Fighters Under International Law (October 2014) at 5; and Orla Hennessy The Phenomenon of Foreign Fighters in Europe: ICCT Background Note (International Centre for Counter-Terrorism, The Hague, July 2012) at 2 .

124 (9 December 2014) 702 NZPD 1207 per Kennedy Graham MP (second reading).

125 New Zealand Law Society "Law Society urges reduction of terrorist fighter bill powers" (press release, 27 November 2014).

126 (9 December 2014) 702 NZPD 1207. Other SOPs include No 43, introduced by Winston Peters MP seeking to re-enact seditious offences (defeated); No 40, introduced by Rt Hon John Key, preventing the delegation of authorisation powers (passed); and No 41, introduced by Kennedy Graham MP, that sought to bring forward the sunset clauses for the provisions and remove the warrantless surveillance power.

127 (9 December 2014) 702 NZPD 1207 per Kennedy Graham MP (committee of the whole house).

128 Supplementary Order Paper 2014 (42) Countering Terrorist Fighters Legislation Bill (1-2) at 2. 
a. meets its obligations under UN Security Council resolution 2178 of 24 September 2014 to combat threats to international peace and security caused by terrorist acts including those perpetrated by foreign terrorist fighters; and

b. ensures that such action by New Zealand remains consistent with its obligations under international human rights law, international refugee law, and international humanitarian law; and

c. ensures that such action by New Zealand is not associated with any religion, nationality, or civilization.

(2) Sections 4IA to 4IG apply to any person suspected of being a foreign terrorist fighter as defined in subsection (3), and to no other person.

(3) Foreign terrorist fighter means a person who travels to a State other than their State of residence or nationality for the purpose of the perpetration, planning, or preparation of, or participation in, terrorist acts or the providing or receiving of terrorist training, including in connection with armed conflict.

The requirements in subs (1) and the definition in subs (3) are taken verbatim from Resolution 2178. ${ }^{129}$ Subsection (1) provides interpretive instruction to the NZSIS and the judiciary that encourages a restrictive view of the powers available. Subsections (2) and (3) serve to streamline the NZSIS's powers to be proportionate with the threat for which they were enacted. In the House, the proposed amendment was supported by the Labour Party as a "reasonable" effort to invoke "greater clarity and greater certainty" into definitions in the Bill. ${ }^{130}$ Precision of legislative drafting is integral to adhering to the principle of legality, and this SOP provides a good vehicle through which New Zealand can improve its provision.

\section{Information retention}

(a) "after the expiry of an authorisation ... if no warrant has been issued"131

A provision that attracted surprisingly little debate in the House was the data retention clause under s $4 \mathrm{IE}(9)$, given that the implications of its drafting potentially undermine several safeguards surrounding the exercise of warrantless surveillance authorisations. This section states that, if no warrant is issued in relation to the authorisation, the Minister must ensure that any records resulting from activities undertaken pursuant to that authorisation are destroyed. However, records may be retained where they are relevant to the detection of activities prejudicial to security, or to the gathering

129 SC Res 2178, above n 15, preamble at 2 and 1 respectively.

130 (9 December 2014) 702 NZPD 1207 per Hon Phil Goff (committee of the whole house).

131 NZSIS Act, s 4IE(9). 
of foreign intelligence essential to security. ${ }^{132}$ The decision to retain records must be referred to the Inspector-General for investigation. ${ }^{133}$ This retention clause provides a route through which the requirements for an authorisation may be systematically undermined.

The provision must be broken down to understand the full extent of what it allows. The phrase "after the expiry of an authorisation" is vague as to the circumstances which amount to an expiry. An authorisation is valid for a period not exceeding 24 hours and it logically follows that an authorisation will expire at the end of this time. However, it is not clear whether the provision applies to authorisations that are discontinued by the Minister or Commissioner. The point of discontinuance could arguably be interpreted as the point of expiry. This interpretation would be consistent with the power given to the Minister or Commissioner under s 4IE(2)(b) to direct the destruction of "any or all of the information collected" because the paragraph provides a discretion to the Minister or Commissioner to direct the retention of information even where the authorisation has been discontinued. If this interpretation is correct, information may be retained even where an oversight authority has terminated the surveillance.

Moreover, the provision does not distinguish between circumstances in which an authorisation was not followed by an application for a warrant, and circumstances in which a warrant was applied for, but denied. The result of the former is that the NZSIS may retain information regarding an individual who may have been erroneously assessed as a terrorist threat or proved to be of no ongoing interest to the NZSIS. A loophole exists where legislation allows the retention of information where the individual will not continue to be subjected to surveillance. The result of the latter is that information may be retained where a subsequent warrant has been denied. A problem arises here because authorisations and warrants are granted on the same set of criteria, albeit assessed by different authorities. If a warrant is denied where an authorisation was supplied, the independent judicial authorities have considered that the standard for the warrant has not been met and therefore that ongoing intrusive surveillance should not be authorised. However, the information retention provision provides a window through which information gathered under authorisation may be retained, despite the circumstances not meeting the standard for a warrant.

Finally, the provision does not limit the ability to retain information gathered during authorisations deemed appropriate by oversight authorities. The Minister and Commissioner must determine whether an authorisation not followed by a warrant application was appropriate to be given and refer the matter to the Inspector-General. ${ }^{134}$ Furthermore, the Inspector-General has a role of investigation where a warrant application is refused. ${ }^{135}$ This lack of specificity leaves open the

132 Section $4 \operatorname{IE}(9)$.

133 Section $41 \mathrm{E}(10)$.

134 NZSIS Act, s 4IE(7).

135 Section 4IE(8). 
possibility that information may be retained where oversight authorities have determined that the authorisation should not have been given.

(b) On grounds of "security"

A second issue with the retention clause is the breadth of the grounds upon which information may be retained. The Special Rapporteur on the promotion and protection of the right to freedom of opinion and expression expressed concern over vague and unspecified notions of national security that have become an acceptable justification for surveillance: ${ }^{136}$

The use of an amorphous concept of national security to justify invasive limitations on the enjoyment of human rights is of serious concern. The concept is broadly defined and is thus vulnerable to manipulation by the State as a means of justifying actions that target vulnerable grounds such as human rights defenders, journalists or activists.

As an illustration, the United Nations Human Rights Committee seventh periodic report of the United Kingdom stated that access to communications data should be "limited to the extent strictly necessary for the prosecution of the most serious crimes". ${ }^{137}$

The information retention clause applies to information about activities that may be prejudicial to "security". "Security" is defined in s 2 of the New Zealand Security Intelligence Service Act as:

(a) the protection of New Zealand from acts of espionage, sabotage, and subversion, whether or not they are directed from or intended to be committed within New Zealand:

(b) the identification of foreign capabilities, intentions, or activities within or relating to New Zealand that impact on New Zealand's international well-being or economic well-being:

(c) the protection of New Zealand from activities within or relating to New Zealand that-

(i) are influenced by any foreign organisation or any foreign person; and

(ii) are clandestine or deceptive, or threaten the safety of any person; and

(iii) impact adversely on New Zealand's international well-being or economic well-being:

(d) the prevention of any terrorist act and of any activity relating to the carrying out or facilitating of any terrorist act.

136 Frank La Rue Report of the Special Rapporteur on the promotion and protection of the right to freedom of opinion and expression A/HRC/23/40 (2013) at [60].

137 United Nations Human Rights Committee Concluding observations on the Seventh Periodic Report of the United Kingdom of Great Britain and Northern Ireland CCPR/C/GBR/CO/7 (2014) at [24(d)]. 
It is clear that terrorism itself is only a subset of the breadth of the concept of security. In its submission on the Bill, the Law Society pointed to the fact that neither the commission of an offence nor a risk to life or safety feature in a provision regarding national security. ${ }^{138}$

The generous scope of the retention clause is especially peculiar given that, following a select committee recommendation, subs $4 \mathrm{ID}(1)$ was amended to provide that authorisations for warrantless surveillance must only be granted for counterterrorism activities. The purpose of this amendment was to reduce the scope of the power, which originally stood on grounds of security, and bring the provision within the counterterrorism intent of the Bill. ${ }^{139}$ Further, the statutory mechanism to ensure deletion of information provides for a fine of up to $\$ 10,000$ for knowing failure to delete records resulting from activities taken pursuant to an authorisation. This amount was increased from $\$ 1,000$ following select committee recommendation in order to reflect the seriousness of the offence. ${ }^{140}$ Similarly, the Law Society supported this increase stating that a firmer safeguard would strengthen the obligation to put in place "appropriate policies and procedures to ensure the Bill is complied with". 141

Both of these increased safeguards are systematically undermined by the information retention clause. The clause circumvents the counterterrorism intent of the power by allowing any information collected to be retained on grounds of national security. It then undermines the safeguard against failure to delete records by legalising the retention of information that was never authorised to be collected.

(c) Other Commonwealth jurisdictions

It may be helpful to contrast New Zealand's approach to information retention with that of the other Commonwealth jurisdictions in order to identify threads of good practice.

Australian legislation has no provision tailored specifically to the retention of information gathered pursuant to a Director-authorised emergency warrant. However, s 31 of the ASIO Act states that information gathered pursuant to a warrant "shall" be destroyed where it is no longer required for the "purposes of the performance of functions or exercise of powers under this Act". ${ }^{142}$ The "functions" and "powers" under the Act reference varied forms of domestic surveillance which are granted on grounds of detecting activities "prejudicial to security" or "important in relation to

138 New Zealand Law Society "Submission to the Foreign Affairs, Defence and Trade Committee on the Countering Terrorist Fighters Legislation Bill 2014" at [28].

139 Countering Terrorist Fighters Legislation Bill 2014 (1-2) (select committee report) at 5.

140 At 5 .

141 New Zealand Law Society, above n 138, at [29].

142 Australian Security Intelligence Organisation Act (Aus), s 31(c). 
security". ${ }^{143}$ United Kingdom legislation requires that information is destroyed as soon as there are no longer any grounds for retaining it as necessary for any of the "authorised purposes" under a warrant, information necessary for carrying out the functions of the Secretary of State or Interception of Communications Commissioner or Tribunal, and where it is necessary for criminal prosecution. ${ }^{144}$ Authorised purposes include national security; prevention of serious crime; safeguarding the economic well-being of the United Kingdom; or giving effect to international mutual assistance agreements. ${ }^{145}$ Finally, Canada's legislation allows the retention of information respecting activities that "may on reasonable grounds be suspected of constituting threats to the security of Canada". ${ }^{146}$

This analysis shows that information retention provisions are not uncommon in Commonwealth legislation. Australian and Canadian legislation limits information retention to the purposes for which warrants are granted in the first instance. In the case of the United Kingdom, information retention is allowed upon the grounds for which a warrant is granted, coupled with the practical operation of oversight and judicial mechanisms. None of the three sets of legislation allow for such a considerable overbreadth of information retention when compared with the grounds for which the information was authorised to be gathered. Thus, to address the loophole in $s 4 \operatorname{IE}(9)$, it is imperative that the information retention clause is restricted to information regarding the activities of foreign terrorist fighters only where an authorisation has been followed by a warrant or approved as reasonable by the Inspector-General. Thereby, the clause will facilitate the retention of records that were collected on a solid legal foundation.

\section{B Citizens as Subjects of Rights and Justified Limits}

Resolution 2178 impleaded states to adhere to their international human rights obligations, stating that failure to comply with these obligations is one of the factors that contributes to increased radicalisation and fosters a sense of impunity. ${ }^{147}$ Moreover, failure to restrict counterterrorism laws poses the risk that those laws will offend the principle of proportionality that governs the permissibility of restriction on human rights and fundamental freedoms. ${ }^{148}$

The key right protected under New Zealand's domestic law that is implicated in warrantless surveillance powers is that in s 21 of the NZBORA: "[e]veryone has the right to be secure against

143 Sections 25(2), 25A(2), 26(3), 26B(2), 26C(2), 27, 27AA(3) and 27AA(6).

144 Regulation of Investigatory Powers Act (UK), s 15(3)-(4).

145 Section 5(3).

146 Canadian Security Intelligence Service Act (Can), s 12(1).

147 SC Res 2178, above n 15, preamble at 2.

148 Martin Scheinin, above n 76, at [26]; Office of the United Nations High Commissioner for Human Rights, above $\mathrm{n} 99$, at 24 . 
unreasonable search or seizure, whether of the person, property, or correspondence or otherwise. "149 Commentary to the draft article of the White Paper on the Bill of Rights noted that the right applied "not only to acts of physical trespass but to any circumstances where state intrusion on an individual's privacy is in this way unjustified" and explicitly noted that the protection should extend to "electronic interception of private conversations, and other forms of surveillance". 150

Secondly, surveillance programmes may constitute a chilling effect on freedom of expression, as including the "freedom to seek, receive, and impart information and opinions of any kind in any form". ${ }^{151}$ This right is protected within s 14 NZBORA and art 19 of the ICCPR. Freedom of expression includes all forms of electronic and internet-based modes of expression. ${ }^{152}$

Thirdly, art 17 of the ICCPR, to which New Zealand is a party, states that "[n]o one shall be subjected to arbitrary or unlawful interference with his privacy, family, home or correspondence". 153 The Human Rights Committee in its General Comment on the article, indicated that it applies to searches and "[s]urveillance, whether electronic or otherwise, interceptions of telephonic, telegraphic and other forms of communication, wire-tapping and recording of conversations". ${ }^{154}$ The New Zealand Supreme Court in $R v$ Hamed adopted this interpretation. ${ }^{155}$ Notably, the United Nations Human Rights Committee has stated that counterterrorism "measures should be taken to ensure that any interference with the right to privacy complies with the principles of legality, proportionality and necessity". 156

The Ministry of Justice provided legal advice to the Attorney-General for consistency of the Bill with the NZBORA. The report drew significantly on jurisprudence regarding warrantless surveillance powers available to the police under the Search and Surveillance Act 2012 and acknowledged safeguards that are not exclusively judicial, but include parliamentary and executive oversight. The legal advice emphasised the capacity of the courts to exclude evidence obtained as a result of an

149 New Zealand Bill of Rights Act 1990, s 21.

150 Geoffrey Palmer "A Bill of Rights for New Zealand: A White Paper" [1984-1985] I AJHR A6 at [10.152]. See also Law Commission Search and Surveillance Powers (NZLC R79) at [2.15].

151 New Zealand Bill of Rights Act, s 14.

152 United Nations Human Rights Committee General Comment No. 34 on Article 19 (2001) at [12].

153 ICCPR, above n 104, art 17.

154 United Nations Human Rights Committee CCPR General Comment No 16: Article 17 (Right to Privacy), The Right to Respect of Privacy, Family, Home and Correspondence, and Protection and Honour of Reputation (1988) at [8].

$155 R$ v Hamed [2011] NZSC 101, [2012] 2 NZLR 305 at [18] per Elias CJ.

156 United Nations Human Rights Committee, above n 137, at [24(a)]. 
unreasonable search from a subsequent criminal trial. ${ }^{157}$ It concluded that the limitations "have the important objective of protecting national security, public order, safety and the rights of others" and are "rationally connected with this objective, proportional, and minimally impairing of rights". 158 However, the Law Society criticised the Ministry's advice in regard to the passport denial provisions as focusing on justifying a restriction that is already permissible at law without considering the appropriateness of the length of the passport denial term, which was the issue on this point, and was not addressed or justified in the Ministry's advice. ${ }^{159}$ A similar argument can be made on the Ministry's analysis of warrantless surveillance powers. The advice laboured to justify the concept of warrantless powers in urgency as a legitimate exception to an individual's right to be free from unreasonable search and seizure. However, the general concept of warrantless surveillance in exceptional circumstances as a justified exception to the right to be free from unreasonable search and seizure, at least for law enforcement officials, is well established. ${ }^{160}$

The circumstances in which an authorisation may be given, oversight mechanisms, and length were not considered or justified by the advice. Given the time period in which the legislation was passed, it is unsurprising that the Ministry of Justice advice is less rigorous and extensive than ideal. The Law Commission's detailed report prior to the enactment of warrantless surveillance powers for the police provides an example of how the analysis of the justifiability, share and scope of any warrantless surveillance powers for New Zealand's security intelligence services should have been undertaken. In that context, the Law Commission stated that "[t]he exceptional nature of such powers makes it essential to codify their existence and scope" and therefore considered three issues of statutory drafting: the offence for which surveillance without warrant ought to be available; the approval process that should precede or follow its use and the maximum period over which surveillance without warrant should be conducted. ${ }^{161}$ These issues will be considered here in relation to warrantless surveillance powers for the NZSIS.

The first issue regards the offence for which surveillance without a warrant ought to be available. Reminiscent of the principle of legality argument in the preceding section, there exists a mismatch between the threat that the Bill sought to address, and the breadth of the powers that have been enacted. As enacted, the warrantless surveillance powers are potentially applicable to any individual who falls within the realm of reasonable suspicion of commission or facilitation of a terrorist act. However, this breadth is in contrast to the more limited purpose of the Bill that was to counter foreign

157 Ministry of Justice Legal Advice: Consistency with the New Zealand Bill of Rights Act 1990: Countering Terrorist Fighters Legislation Bill (12 November 2014) at [4].

158 At [4].

159 New Zealand Law Society, above n 125, at [9].

160 Law Commission, above n 150, at [2.67].

161 At [5.5] and [11.108] 
terrorist fighters, representing a smaller subset of the terrorist threat. As a result, the provision is not drafted to minimally impair the right to privacy because it may subject individuals not within the purview of the Parliament enacting the legislation to intrusive surveillance. While Australia and the United Kingdom both contain powers of urgent surveillance within their security legislation that are available on wider grounds than the NZSIS, New Zealand's powers were enacted for a specific purpose and must be limited as such in order to uphold New Zealand citizens' rights to the fullest extent.

The next issue is the extent to which an approval process should be provided. On this issue, legislative review should consider the inconsistencies between New Zealand and other Commonwealth nations as a concern that New Zealand has expanded its powers to an unjustifiable extent. Currently, New Zealand's statute allows the Director-General to make an authorisation and then immediately inform the Minister, Commissioner and Inspector-General who may discontinue the surveillance. ${ }^{162}$ In comparison, Canada adheres to the strict judicial warrant procedure. ${ }^{163}$ Australia's precedent requires a warrant application to be made before surveillance can be internally authorised. ${ }^{164}$ The United Kingdom requires urgent authorisation to be made by the Secretary of State, who is the actor who approves warrants in the ordinary course of affairs. ${ }^{165}$ Each of these jurisdictions require the warrant process to have progressed further before an emergency warrant can be granted, if at all. As a result, New Zealand's legislation, as currently enacted, can be seen to strip away safeguards of the right to privacy and unreasonable search and seizure that exist in other jurisdictions.

The final issue is the maximum period for which the emergency use of surveillance should be permitted. The present authorisation extends for 24 hours. ${ }^{166}$ Canada allows for no emergency authorisation. ${ }^{167}$ Australia's legislation provides for 48 hours, but recall that a warrant application must already have been made, therefore, the period for which the emergency warrant stands is dependent only on the Minister's consideration and issuance of a warrant. ${ }^{168}$ The United Kingdom allows for five working days, but this provision is tailored to an emergency situation in which the Secretary of State is not physically available to sign the warrant, but will still personally authorise the

162 NZSIS Act, s 4IE(2).

163 Canadian Security Intelligence Service Act (Can), s 21(1).

164 Australian Security Intelligence Organisation Act (Aus), s 29(1)(a).

165 Regulation of Investigatory Powers Act (UK), ss 7(2)(a), 42(1) and 44(2).

166 NZSIS Act, s 4ID(3).

167 Canadian Security Intelligence Service Act (Can), s 21(1).

168 Australian Security Intelligence Organisation Act (Aus), ss 29(1)(a) and 29(2). 
surveillance activity. ${ }^{169}$ A window of 24 hours of warrantless surveillance without authorisation by an independent judicial authority in New Zealand stands out from these examples as prolonging the amount of time under which an individual's right to privacy and freedom from unreasonable search may be impacted on through warrantless surveillance.

There is a mismatch between New Zealand's legislation and both its overseas counterparts and its obligations to protect the human rights of its citizens. To amend these issues, New Zealand's Privacy Commissioner would strengthen the obligation to notify the Minister and Commissioner to require the application for a warrant to be made within 12 hours. Under this approach, the surveillance would be positively authorised by the Minister and Commissioner, rather than being subject to discontinuance. ${ }^{170}$ This recommendation is still considerably weaker than our Commonwealth counterparts, but bolsters the support for a more restrictive view of surveillance in urgent situations. An alternative, and preferable, amendment would be to have the Minister and or Commissioner give the authorisation, pending a 12 hour window in which a warrant application must be made. If the Director is able to assess whether the warrant threshold is met and subsequently notify the Minister and Commissioner, there does not seem to be any reason not to require the Director to immediately notify the Minister and Commissioner of the relevant evidence and have these authorities issue an authorisation, similar to the United Kingdom requirement. The statement by the Law Commission in regard to police warrantless surveillance powers that "[if] there is time to obtain internal approval then there ought to be sufficient time to obtain a telewarrant" supports this conclusion. ${ }^{171}$ This formulation would mean that an external oversight authority gives the authorisation itself.

\section{CONCLUSION}

The latest and most recent manifestation of the terrorist threat is that of the foreign terrorist fighter. As a result of combined international pressure and increase of the domestic threat level at home, and in order to increase domestic capacity to respond to these threats, New Zealand has enacted emergency powers for the NZSIS. The Bill introduced the ability to conduct warrantless surveillance for 24 hours where there is an actual, potential or suspected terrorist act or facilitation of a terrorist act. The Bill was rushed through Parliament under urgency, resulting in significant shortcuts in terms of public and external consultation. As a result, the Bill presents several shortcomings.

The Department of Prime Minister and Cabinet provided incomplete information to the Select Committee that did not emphasise the stark differences between the provisions of Australia, the United Kingdom and New Zealand in the context of emergency surveillance. Whereas privacy rights

169 Regulation of Investigatory Powers Act (UK), ss 9(6), 7(2)(a), 42(1) and 44(2).

170 Privacy Commissioner, above n 9, at 3 .

171 Law Commission, above n 150, at [11.112]. 
are upheld by the warrant procedure, New Zealand has taken a significant step further than our Commonwealth partners in eroding this right.

The use of the term "terrorist act" offends the principle of legality. The definition itself is vague, with the potential to be applied very broadly. Its breadth does not distinguish between domestic threats and foreign terrorist fighters, thereby extending the power of warrantless surveillance over actors who did not and do not present a threat large enough to justify intrusive state powers. The enactment also contains an information retention clause that creates a significant loophole in the legislation. The Ministry of Justice's advice on consistency of the Bill with NZBORA did not acknowledge the true complexities of the power. While in the context of police powers warrantless searches have been found to be reasonable by the courts, discussion of the shape and scope of the newly enacted powers and their impact on unreasonable search and seizure remained unaddressed and unjustified. ${ }^{172}$

However, in accordance with s 21 of the Intelligence and Security Committee Act 1996, a review of the intelligence and security agencies, the legislation governing them, and their oversight legislation must have been commenced before 30 June $2015 .{ }^{173}$ In the security intelligence context, in which outside debate is precluded by redactions and withheld information, the review will provide a vital forum for deeper analysis of the issues that have been raised in this article and others, including recourse for individuals subject to surveillance, guidance to the courts, the efficacy of the InspectorGeneral as an oversight mechanism and, most importantly, the necessity of warrantless surveillance powers at all in the security intelligence context.

$172 R v$ Williams [2007] NZCA 52, 3 NZLR 207 at [123]; $R v$ Ngan [1007] NZSC 105, [2008] 2 NZLR 48 at [112]; and British Columbia Securities Commission v Branch [1995] 2 SCR 3.

173 Intelligence and Security Committee Act 1996, s 21(1). 